\title{
Beycuma Korucuk Köyü'ndeki (Zonguldak) Servi Ağacının Anıtsal Özellikleri
}

\author{
Barbaros YAMAN $^{1 *}$, Ruhi KÖKTÜRK ${ }^{2}$ \\ ${ }^{1 *}$ Bartın Üniversitesi, Orman Fakültesi, Orman Mühendisliği Bölümü, 74100, Bartın \\ ${ }^{2}$ Korucuk Köyü, Beycuma, Zonguldak
}

\section{Öz}

Beycuma (Zonguldak) Korucuk Köyü’ndeki anıtsal özellikleri incelenen ağaç Cupressaceae familyasında yer alan Cupressus sempervirens L. (Akdeniz servisi) türüne aittir. Anıt Ağaç Envanter Karnesi ve Anıt Ağaç Değerlendirme Formunda belirtilen somut ve soyut özellikler çerçevesinde bu ağaç için hesaplanan Şimdiki Anıtsal Değer (ŞAD) 50'dir. Literatürde Akdeniz servisi için belirlenen Asgari Anıtsal Değer (AAD Tür) 38 olarak verilmektedir. Buna göre; ŞAD $>\mathrm{AAD}_{\text {Tür }}$ olduğu için Korucuk Köyü’ndeki bu ağacın boyutsal anıt ağaç olarak tescil edilmesi gerekir. Ağacın negatif puanları toplamı -6 olmakla birlikte, gövde üzerindeki yoğun orman sarmaşı ̆̆ (Hedera helix L.) ve kümes olarak kullanılan kovuk kısım nedeniyle bu anıt servinin ivedilikle bakım ve koruma altına alınması gerekmektedir. Yöredeki Köktürk soyadlı ailelerden alınan bilgiler ve literatür temelinde bu ağacın 18. yüzyıl Osmanlı Sadrazamlarından İzzet Mehmed Paşa'nın babası Hüseyin Bey ile ilişkili olabileceği düşünülmektedir. Bu çerçevede incelenen ağacın tarihsel anıt ağaç olduğu da söylenebilir.

Anahtar Kelimeler: Anıt Ağaç, Akdeniz Servisi, Cupressaceae, Cupressus sempervirens, Korucuk Köyü.

\section{Monumental Traits of a Mediterranean Cypress Tree in Beycuma Korucuk Village (Zonguldak)}

\begin{abstract}
Mediterranean cypress tree (Cupressus sempervirens L.) whose monumental traits we examined is located in Korucuk village in Beycuma, Zonguldak. According to measurable and unmeasurable criteria stated in the monumental tree inventory scorecard and monumental tree assessment form, the tree scored 50 points. Since this score is above the minimum monumental tree score (38 points) given as a threshold value for Mediterranean cypress species, the tree is considered a monumental tree. The negative score of the tree is 6 because of the English ivy and hollowness on its stem. Therefore, the necessary treatments and measures should be taken immediately. The narratives of the families with Köktürk surname in the region, the regional historical literature, and the calculated tree age (age class: 301-400) strengthen that this cypress tree might have a connection to the father (Huseyin Bey) of Grand Vizier Izzet Mehmed Pasa serving in the Ottoman Empire in the 18th century. Therefore, it can be argued that this tree is also a historic monument tree.
\end{abstract}

Keywords: Monumental tree, Cupressaceae, Cupressus sempervirens, Mediterranean cypress, Korucuk village. 


\section{Giriş}

Axel Erlandson (1884-1964) Kaliforniya'daki bir çiftlikte genç ağaçların gövde ve dallarına değişik teknikler (aş1, budama, eğme, bükme, örme) uygulayarak 1947'de bir park meydana getirmiştir (URL-1, Yaman 2005). Kaliforniya Gilroy’da Bonfante Bahçeleri olarak bilinen bu park sahip olduğu ilginç formlu ağaçlarıyla bugün ziyaretçilerin en fazla ilgisini çeken yerlerden birisidir. Bonfante Bahçeleri'ndeki bu ağaçların ilginç formları Erlandson'un genç ağaçlara fidan aşamasında bilinçli müdahalesi sonucu oluşmuştur. Oysa dünyamızda yüzyıllarca yaşam mücadelesi vererek hayatta kalmayı başarmış, genetik özellikler ve çevre koşulları gibi doğal süreçlerin etkisiyle, yaş, çap ve boy bakımından kendi türünün olağan sınırlarını aşmış anıtsal özellikler taşıyan çok sayıda ağaç bulunmaktadır (Yaman 2005).

Dünyanın en yaşlı ağacı Amerika Birleşik Devletleri (ABD) Akdağlar'da (White Mountains) yaşayan 5071 yaşındaki bir Pinus longaeva D. K. Bailey bireyidir (URL-2). ABD'de Sekoya Ulusal Park'ındaki Hyperion olarak da adlandırılan 115,7 m uzunluğundaki Sahil sekoyası (Sequoia sempervirens (D.Don) Endl.) dünyanın en uzun boylu ağacı olarak kabul edilmektedir (URL-3). İlk iki sırayı paylaşan en geniş gövdeli ağaçlar ise 30 m'nin üzerinde çevresi olan ve Kaliforniya Sierra Nevada Dağları'nda yaşayan Mamut ağacı (Sequoiadendron giganteum (Lindl.) J.Buchholz) ile Meksika’da yaşayan bir Bataklık servisidir (Taxodium mucronatum Ten.). Bunlardan “General Sherman” adlı Mamut Ağacı dünyanın en hacimli ağacı olarak kabul edilmektedir (dikili kabuklu gövde hacmi $1486 \mathrm{~m}^{3}$, tahmini yaşı 2300-2700) (URL-4).

Uygarlık tarihi boyunca tahrip edilen Anadolu ormanlarında ve bu ormanlardan günümüze ulaşan kalıntı ormanlar içerisinde hala çok sayıda anıt nitelikli ağaç bulunabilmektedir (Yaman 2005, Kırsal Çevre 2019). Türkiye hem tür çeşitliliği hem de sayıca, geçmişte bazı tahripler olsa da, anıt nitelikli ağaçlar yönünden zengin bir ülkedir. Özellikle Toros sediri, karaçam, sarıçam, adi porsuk, doğu çınarı ile ardıç ve meşenin farklı türlerinin anıt nitelikli bireylerine ülkenin farklı coğrafyalarında rastlanmaktadır. Son yıllarda Türkiye'nin en yaşlı anıt ağaçlarından birisi de Alaplı (Zonguldak) Gümeli'de tespit edilen adi porsuktur (Taxus baccata L.). Yaşı üzerinde bazı tartışmalar olsa da dendrokronolojik analizler bu porsuk ağacının yaklaşı 2000 yaşında olabileceğini göstermiştir (Akkemik ve ark. 2018).

Türkiye'nin Batı Karadeniz Bölgesi'ndeki kayda girmemiş anıt özelliklere sahip ağaçlar Sarıbaş (2015) tarafından incelenmiştir. Ancak Zonguldak, Beycuma, Korucuk Köyü’ndeki Cupressus sempervirens L. (Akdeniz servisi) o tarihte bilinmediği için kapsam dışı kalmıştır. Bu çalışma, türün doğal yayılış alanı içerisinde olmayan ve Osmanlı İmparatorluğu Dönemi'nde Beycuma Beyliği Korucuk Köyü’ne 1600’lü yıllarda dikildiği rivayet edilen yaşlı bir Akdeniz servisinin anıtsal özelliklerini tespit etmek amacıyla gerçekleştirilmiştir.

\section{Materyal ve Metot}

Zonguldak ili, Beycuma, Korucuk Köyü’nde bulunan Akdeniz servisinin anıt ağaç olup olmadığının tespiti amacıyla, Şekil 1'de koordinatları verilen yere 03/11/2020 tarihinde gidilerek inceleme ve ölçümler yapılmıştır.

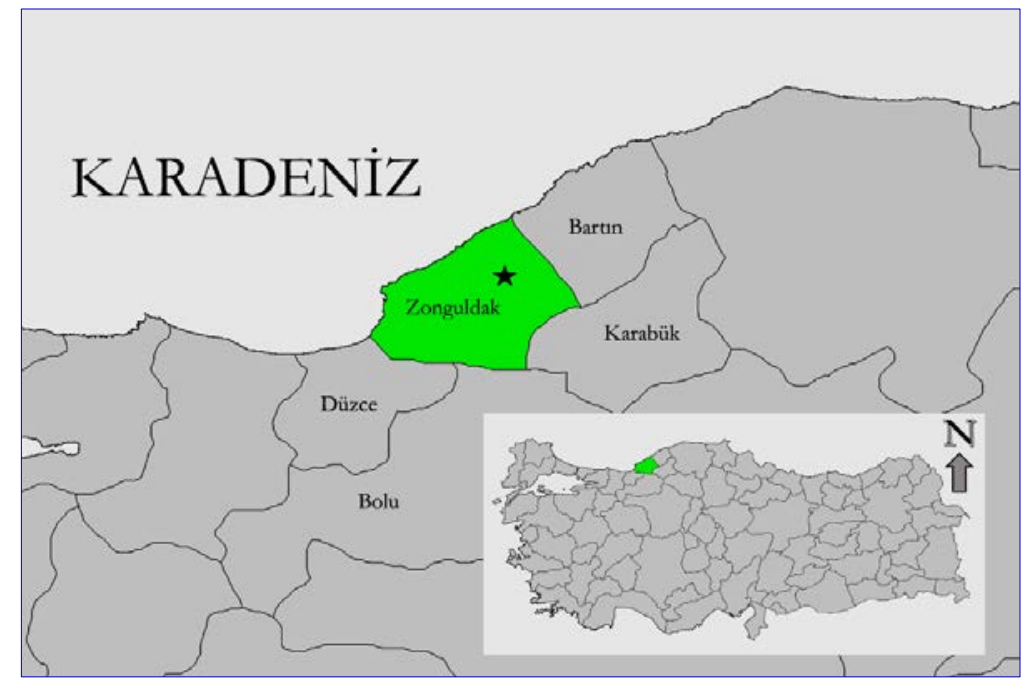

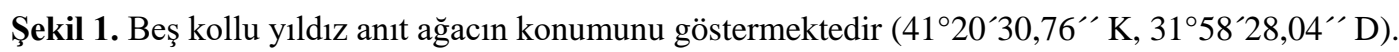


Ölçüm ve değerlendirmelerde anıt ağaçların seçim kuralları ile ilgili Genç ve Güner (2003)'in geliştirdiği yöntem ve bu yöntem temelinde 24.10.2020 tarih ve 31284 sayılı Resmi Gazete'de yayınlanan "Tabiat Varlı̆g 1 Olarak Belirlenecek Anıt Ağaçların Tespitine İlişkin İlke Kararı" başlıklı metinde (Resmi Gazete 2020) belirtilen ilkeler esas alınmıştır. İncelemelerde ayrıca iptal edilen TS 13137 numaralı standart da dikkate alınmıştır (TSE 2005). Öncelikle yaprak, kozalak ve gövde kabuğu özelliklerine dayanılarak inceleme konusu ağacın bitki sistematiğindeki yeri belirlenmiş ve coğrafi koordinatları tespit edilmiştir. Ağaç için anıt ağaç envanter karnesi hazırlanarak, söz konusu karnede belirtilen somut ve soyut özelliklerle ilgili arazide ölçüm ve tespitler yapılmış ve bulgular envanter karnesine işlenmiştir (Genç ve Güner 2003). Tahmini yaş tespiti için artım burgusu kullanılarak, gövdenin göğüs yüksekliğinden $\left(\mathrm{d}_{1,30}\right)$ iki farklı yerden kabuklu boyu $23,4 \mathrm{~cm}$ ve $25,5 \mathrm{~cm}$ olan artım kalemleri alınmıştır. Laboratuvarda enine yüzeyleri üstte olacak şekilde tahta taşıyıcılara sabitlenen kalemler yıllık halka sınıllarının net olarak görülebilmesi için sırasıyla 400 ve 800 kum zımpara ile zımparalanmıştır. Sayım ve ölçüm yapılmadan önce yıllık halkalar, kabuktan öze doğru, 10'ar yıllık seksiyonlar halinde işaretlenerek görsel eşleştirme yapılmışıtır (Akkemik 2004). Artım kalemi uzunluklarının gövde yarıçapının tamamını kapsamadığı durumlarda interpolasyonla yapılan yaş tahmininde, ağacın gençlik yıllarında daha hızlı büyümesi nedeniyle, gerçek yaştan daha fazla yaş değeri ortaya çıkmaktadır. Bu sakıncayı gidermek amacıyla ontogenetik ve fizyolojik olarak daha genç olan öze yakın gövde kısımlarındaki yıllık halka sayısını tahmin etmek için yakın çevrede bulunan aynı türdeki daha genç ağaçlardan da artım kalemi alınarak yaş tahmininde kullanılmaktadır (Yaman ve Sarıbaş 2007, Yaman 2018).

$\mathrm{Bu}$ çalışmada, Akdeniz servisinin bölgenin doğal türü olmaması ve yakın çevrede genç bireylerine rastlanılmaması nedeniyle, genç bireylere ait artım kalemi sağlanamamıştır. Bu nedenle, incelenen ağacın yaşı zorunlu olarak gövde yarıçapının ontogenetik olarak daha yaşlı bölümüne ait kabuksuz boyları 21,5 cm ve 24,4 $\mathrm{cm}$ olan iki adet (sırasıyla A ve B kalemi) artım kaleminin birikimli (kümülatif) yıllık halka genişlikleri temelinde hesaplanan regresyon denklemi kullanılarak tahmin edilmiştir (Akkemik ve ark. 2018, Yaman ve Sarıbaş 2007, Yaman 2018). Boy, gövde çapı, tepe çap1, tahmini yaş, bulunduğu yer, diğer pozitif özellikler ve negatif özellikler için anıt ağaç değerlendirme formu üzerinde gerekli puanlar verilerek ağacın "Şimdiki Anıtsal Değeri” (ŞAD) belirlenmiştir. Aynı zamanda incelenen anıt ağaçla aynı köyde yaşayan ve soyadı Köktürk olan ailelerin kuşaktan kuşağa aktardıkları rivayetlere dayanarak literatür taraması yapılmış ve anıt ağacın tarihsel bağlamı da araştırılmıştır. Ayrıca incelenen servi ağacının görsel durumunu gösteren fotoğraflar da çekilmiştir (Şekil 2, 3 ve 4).

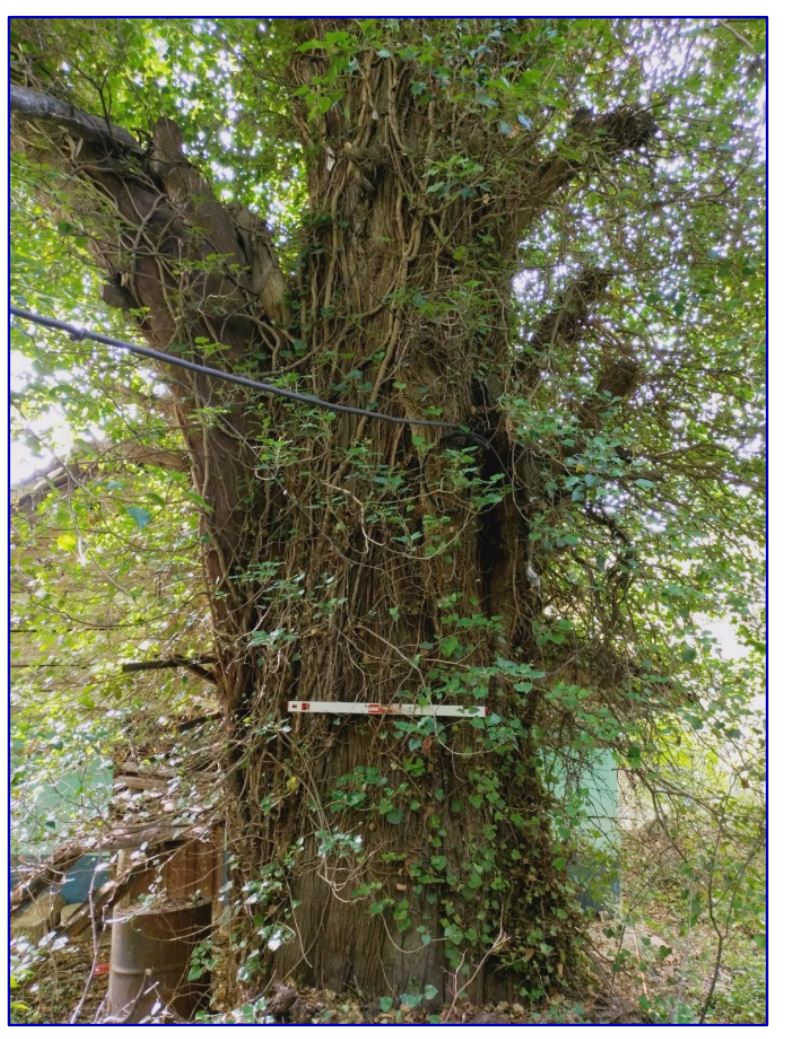

Şekil 2. Anıt ağacin gövde genel görünümü.

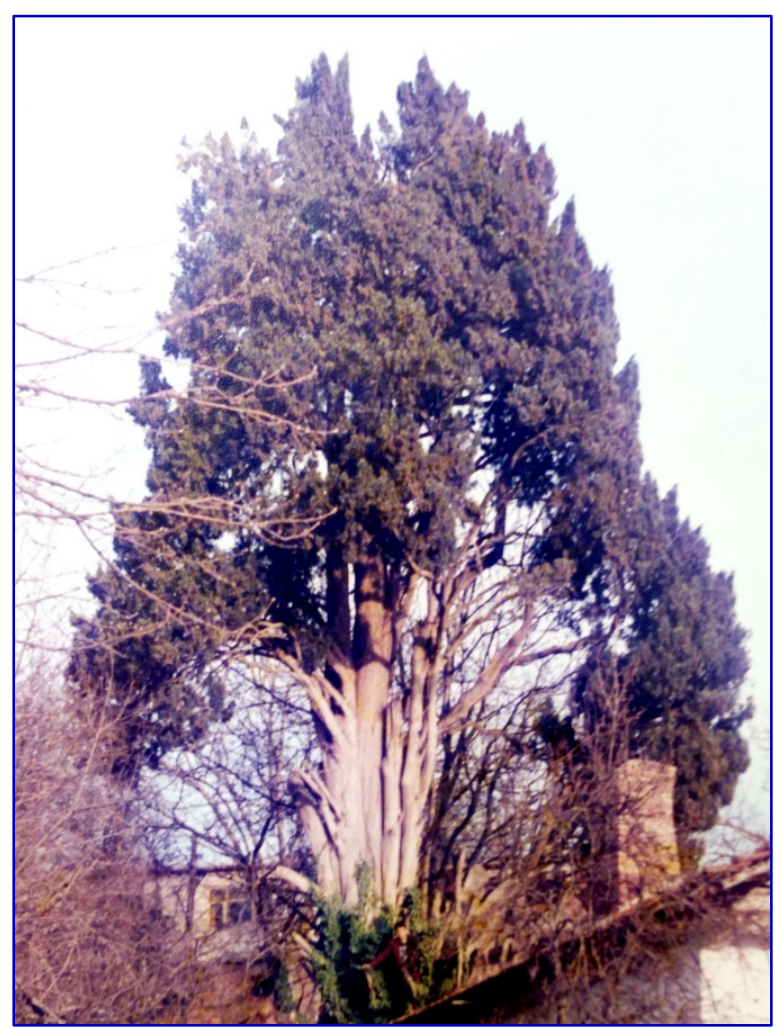

Şekil 3. Anıt ağacın tepe tacı. 


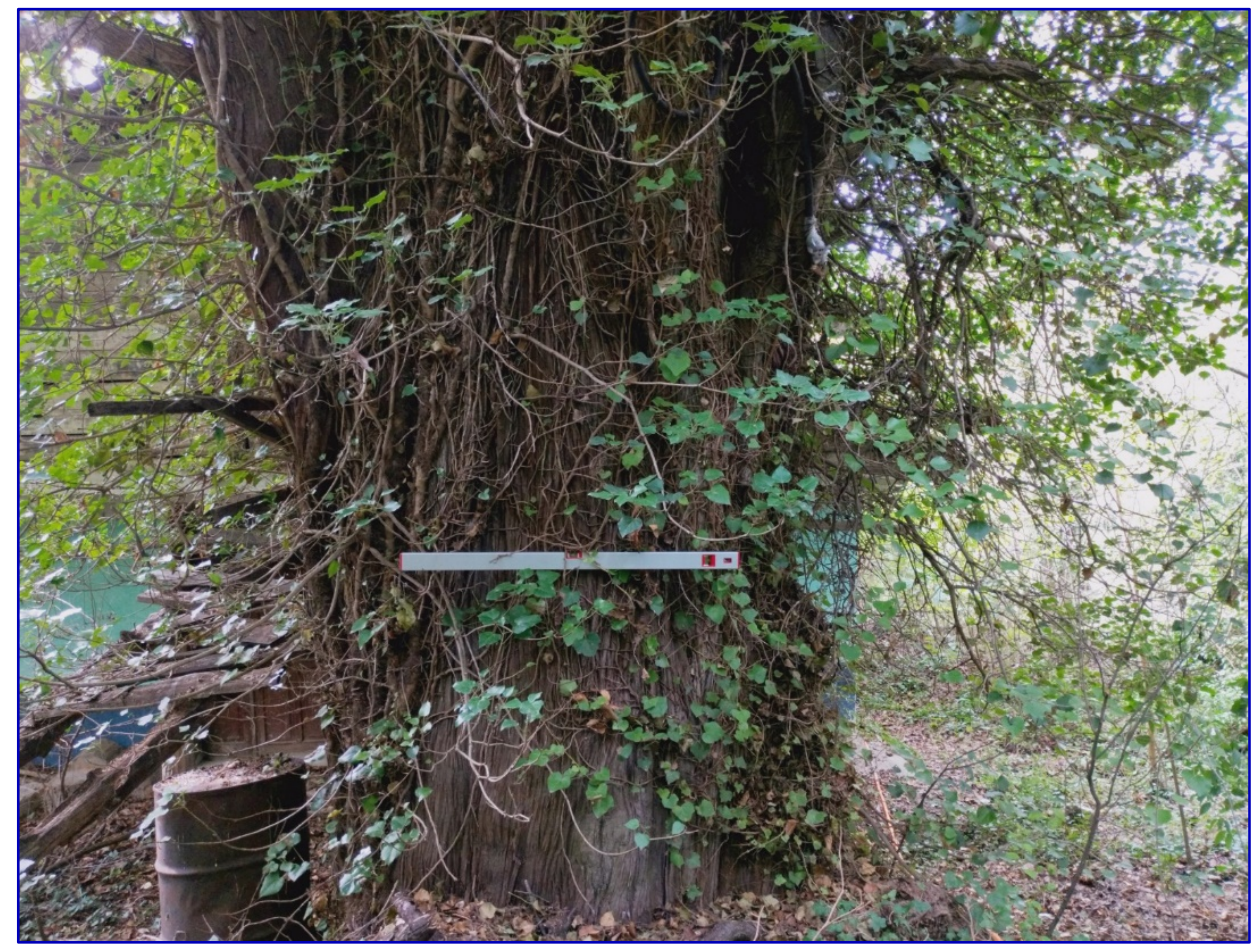

Şekil 4. Gövdenin yakından görünümü ve anıt ağaç için tehdit oluşturan orman sarmaşığı.

\section{Bulgular ve Tartışma}

Araştırma kapsamında incelenen C. sempervirens Zonguldak İli, eski Beycuma nahiyesi yakınında bulunan

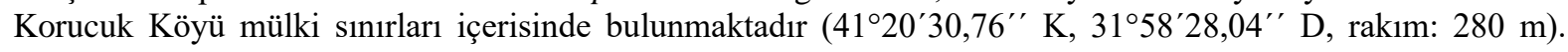
Ağaçtan alınan iki adet artım kalemine ilişkin tespit edilen veriler Tablo 1'de verilmiştir.

Tablo 1. Artım kalemlerine ait veriler.

\begin{tabular}{llll}
\hline Kalem & Kalem Uzunluğu (Kabuksuz) & Halka Sayısı & Kapsadığı Yıllar \\
\hline $\mathrm{A}$ & $21,5 \mathrm{~cm}$ & 130 & $1891-2020$ \\
$\mathrm{~B}$ & $24,4 \mathrm{~cm}$ & 150 & $1871-2020$ \\
\hline
\end{tabular}

Gövdeden alınan A kaleminin birikimli y1llık halka grafiğinden elde edilen regresyon denklemi $\mathrm{y}=1,641 \mathrm{x}-$ 18,311 olup, $\mathrm{R}^{2}$ değeri 0,96 olarak hesaplanmıştır (Şekil 5). B kaleminin birikimli yıllık halka grafiğinden elde edilen regresyon denklemi ise $\mathrm{y}=1,6798 \mathrm{x}-18,629$ olup, $\mathrm{R}^{2}$ değeri 0,99'dır (Şekil 6). C. sempervirens'in tahmini yaşı $\mathrm{R}^{2}$ değeri daha yüksek olan B kalemi ve $63 \mathrm{~cm}$ yarıçap esas alınarak yaklaşık 386 yıl olarak tespit edilmiştir. Ancak, materyal ve metot bölümünde açıklandığ 1 üzere, gövdenin ontogenetik ve fizyolojik olarak genç olan öze yakın bölümündeki daha geniş yıllık halkalar nedeniyle, tahmin edilen bu yaşın bir miktar daha düşük olması gerektiği açıktır. İster regresyon denkleminden elde edilen 386 yıl isterse ondan 40-50 y1l daha küçük bir değer yaş olarak alınsın, incelen ağaç tahmini yaş itibariyle 301-400 yaş sınıfına girmekte ve buradan 9 puan almaktadır. Anıt ağaç değerlendirme formunda belirtilen diğer ölçülebilir somut özellikler çerçevesinde ise gövde çapı sınıfı itibariyle $(125-149 \mathrm{~cm}) 24$, boy sınıfı itibariyle $(15,5-20 \mathrm{~m}) 13$ ve bulunduğu yer itibariyle 4 puan olmak üzere anıt ağacın toplam puanı 50'dir. Tepe çapı ve diğer pozitif özelliklerden aldığı puan 0'dır. Böylece anıtsal özellikleri incelenen bu ağaç için hesaplanan Şimdiki Anıtsal Değer (ŞAD) 50'dir (Tablo 2). Literatürde C. sempervirens için verilen Asgari Anıtsal Değer (AAD) 38'dir (Genç ve Güner 2003). ŞAD > AAD olduğu için söz konusu ağaç boyutsal anıt ağaç özellikleri taşımaktadır. Negatif özellikleri itibariyle, ağaç gövdesinin yamaç tarafındaki dip kısmında, geçmişte kümes olarak kullanıldığı anlaşılan, genişliği gövdenin yaklaşık 1/3'ü büyüklüğünde bir kovuk bulunmaktadır. Ayrıca ağacın bazı alt dallarının eskiden kesilmiş olduğu tespit edilmiştir. Bu nedenle ağaç -6 negatif puana sahiptir. Diğer taraftan gövde üzerinde tepe tacına doğru uzanan yoğun Hedera helix (orman sarmaşığı) işgali bu anıt ağacın yaşamını tehdit etmektedir (Şekil 2 ve 4). İşgalci bir tür olan $H$. helix' in uzun vadede konak ağaçların tepe taçlarına egemen olması durumunda, yıllar içerisinde bu ağaçların ölüme sürüklendiği bilinen bir gerçektir (Yaman 2009a ve 2009b). Bu nedenle anıt özellikler taşıyan C. sempervirens' in bakıma alınması ve korunması gereklidir. 


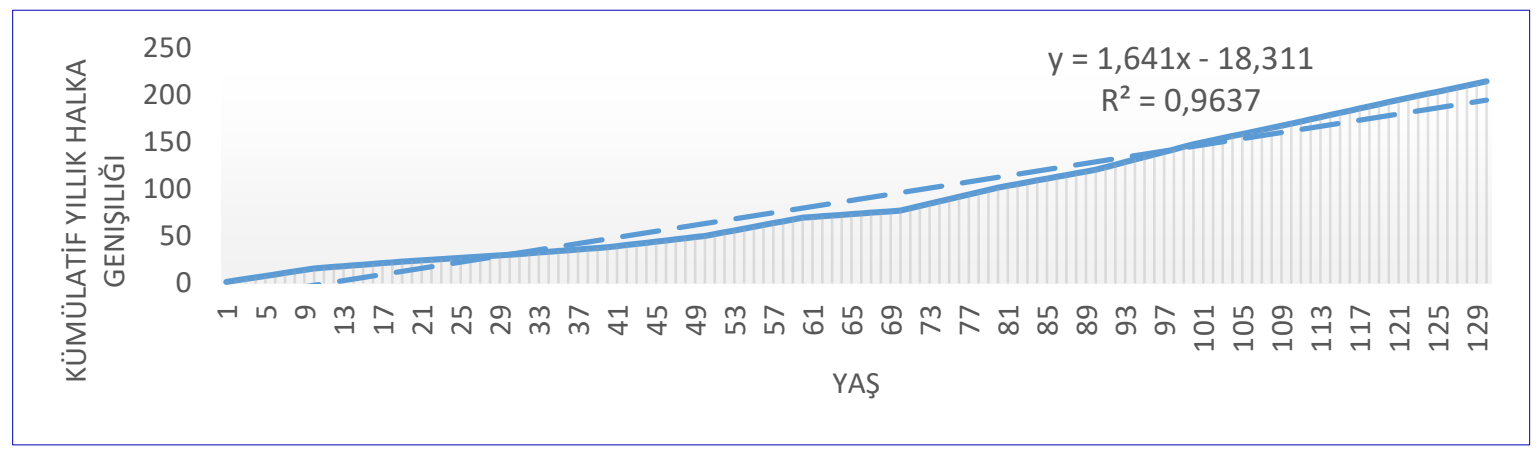

Şekil 5. "A" kodlu artım kaleminde (1891-2020) birikimli ylllık halka gelişimi (düz mavi çizgi). Eğilim kesikli gri çizgi ile gösterilmiştir. Artım kaleminin 21,5 cm'lik kısmında 130 yıllık halka bulunmaktadır.

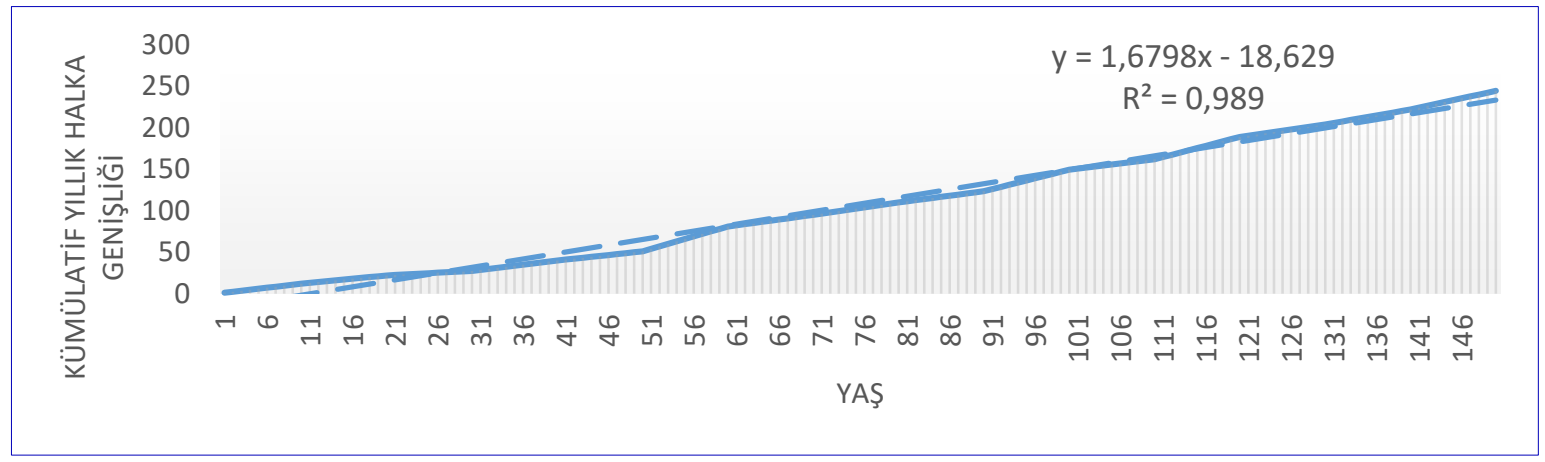

Şekil 6. "B" kodlu artım kaleminde (1871-2020) birikimli yıllık halka gelişimi (mavi çizgi). Eğilim kesikli gri çizgi ile gösterilmiştir. Artım kaleminin 24,4 cm'lik kısmında 150 yıllık halka bulunmaktadır.

Tablo 2. Anıt Ağaç Değerlendirme Formu (Türkiye'nin doğal türleri için).

\begin{tabular}{|c|c|c|c|c|c|c|}
\hline \multirow[t]{2}{*}{ ÖĞELER } & \multirow{2}{*}{$\begin{array}{l}\text { VERİLEBECEK } \\
\text { MAKSIMMUM } \\
\text { PUAN }\end{array}$} & \multirow[t]{2}{*}{$\begin{array}{l}\text { DEĞERLENDİRME } \\
\text { BASAMAKLARI }\end{array}$} & \multicolumn{3}{|c|}{$\begin{array}{l}\text { SINIFINA GÖRE AĞACA } \\
\text { VERİLECEK PUAN }\end{array}$} & \multirow{2}{*}{$\begin{array}{l}\text { VERİLEN } \\
\text { PUAN } \\
\text { SERVI } \\
\end{array}$} \\
\hline & & & I.SINIF & II.SINIF & III.SINIF & \\
\hline \multirow{11}{*}{$\begin{array}{l}\text { Boy } \\
\text { (Bo) }\end{array}$} & \multirow{11}{*}{20} & $05,0-07,5$ & 0 & 0 & 10 & \multirow{11}{*}{13} \\
\hline & & $08,0-10,0$ & 0 & 0 & 20 & \\
\hline & & $10,5-15,0$ & 0 & 6 & 20 & \\
\hline & & $15,5-20,0$ & 0 & 13 & 20 & \\
\hline & & $20,5-25,0$ & 0 & 20 & 20 & \\
\hline & & $25,5-30,0$ & 3 & 20 & 20 & \\
\hline & & $30,5-35,0$ & 6 & 20 & 20 & \\
\hline & & $35,5-40,0$ & 9 & 20 & 20 & \\
\hline & & $40,5-45,0$ & 12 & 20 & 20 & \\
\hline & & $45,5-50,0$ & 16 & 20 & 20 & \\
\hline & & $>50,0 \mathrm{~m}$ & 20 & 20 & 20 & \\
\hline \multirow{12}{*}{$\begin{array}{l}\text { Gövde } \\
\text { Çap1 } \\
\text { (GÇ) }\end{array}$} & \multirow{12}{*}{30} & $<50$ & 0 & 0 & 10 & \multirow{12}{*}{24} \\
\hline & & $50-74$ & 0 & 6 & 20 & \\
\hline & & 75-99 & 0 & 12 & 30 & \\
\hline & & $100-124$ & 3 & 18 & 30 & \\
\hline & & $\underline{125-149}$ & 6 & $\underline{24}$ & 30 & \\
\hline & & $\overline{150-174}$ & 9 & $\overline{30}$ & 30 & \\
\hline & & 175-199 & 12 & 30 & 30 & \\
\hline & & $200-224$ & 15 & 30 & 30 & \\
\hline & & $225-249$ & 18 & 30 & 30 & \\
\hline & & $250-274$ & 22 & 30 & 30 & \\
\hline & & $275-299$ & 26 & 30 & 30 & \\
\hline & & $\geq 300 \mathrm{~cm}$ & 30 & 30 & 30 & \\
\hline
\end{tabular}




\begin{tabular}{|c|c|c|c|c|c|}
\hline $\begin{array}{l}\text { Tepe } \\
\text { Çap1 } \\
\text { (TÇ) }\end{array}$ & 10 & $\begin{array}{l}<\underline{\mathbf{0 5}, \mathbf{0}} \\
05,0-09,5 \\
10,0-14,5 \\
15,0-19,5 \\
\geq 20 \mathrm{~m}\end{array}$ & $\begin{array}{l}0 \\
2 \\
4 \\
7 \\
10\end{array}$ & $\begin{array}{l}3 \\
6 \\
10 \\
10 \\
10\end{array}$ & 0 \\
\hline $\begin{array}{l}\text { Tahmini } \\
\text { Yaş } \\
\text { (Ya) }\end{array}$ & 30 & $\begin{array}{l}100-200 \\
201-300 \\
\mathbf{3 0 1 - 4 0 0} \\
401-500 \\
501-600 \\
601-700 \\
701-800 \\
801-900 \\
901-1000 \\
>1000 Y_{11} \\
\end{array}$ & $\begin{array}{l}3 \\
6 \\
9 \\
12 \\
15 \\
18 \\
21 \\
24 \\
27 \\
30 \\
\end{array}$ & & 9 \\
\hline $\begin{array}{l}\text { Bulunduğ } \\
\text { u Yer } \\
\text { (BY) }\end{array}$ & 10 & $\begin{array}{l}\text { Ormanda [ağaçlık } \\
\text { çağındaki bir toplumda } \\
\text { ve bulunduğu alan } \\
\text { meşcereden } \\
(1 \text { ha) büyük] } \\
\text { Meşcerede (kırsalda- } \\
\text { kentte) } \\
\text { Grupta (kırsalda- } \\
\text { kentte) } \\
\text { Kümede (kırsalda- } \\
\text { kentte) } \\
\text { Tek (kırsalda) } \\
\text { Tek (kentte) }\end{array}$ & $\begin{array}{l}10 \\
9 \\
8 \\
\frac{4}{6}\end{array}$ & & 4 \\
\hline $\begin{array}{l}\text { Diğer } \\
\text { Pozitif } \\
\text { Özellikler } \\
\text { (PÖ) }\end{array}$ & 10 & $\begin{array}{l}\text { Ağaç için zorunlu } \\
\text { yetişme ortamı } \\
\text { faktörlerinin korunması } \\
\text { mümkün } \\
\text { Sağlıklı } \\
\text { En az bir anıtsal } \\
\text { özelliği (boyu, çapı yaşı } \\
\text { gibi) bakımından } \\
\text { dünyada veya } \\
\text { Türkiye'de sayılı bir } \\
\text { ağaç olması } \\
\text { Özzellikli (doğal } \\
\text { halinin dısında kabuk, } \\
\text { yaprak, çiçek, meyve } \\
\text { veya kozalak, dallanma, } \\
\text { çatallanma, gövde } \\
\text { şekillenmesi vb. } \\
\text { özelliklerce farklı) } \\
\text { D Hiçbiri }\end{array}$ & $\begin{array}{l}6 \\
9\end{array}$ & & 0 \\
\hline $\begin{array}{l}\text { Negatif } \\
\text { Özellikler } \\
\text { (NÖ) }\end{array}$ & -10 & $\begin{array}{l}\text { Ağaç için zorunlu } \\
\text { yetişme ortamı } \\
\text { faktörlerinin korunması } \\
\text { mümkün değil } \\
\text { Tepe Çökmesi } \\
\rightarrow \text { İlerlemiş (tepede } \\
\text { yoğun kuruma) } \\
\rightarrow \text { Yeni } \\
\text { Böcek-Mantar Zararı } \\
\text { (Tepe çökmesi yoksa } \\
\text { değerlendirmeye katılır) } \\
\text { - Gövde kovuk } \\
\rightarrow \text { Genişliği } 1 / 5 \Theta \\
\rightarrow \text { Genişliği=1/5-1/3 } \Theta \\
\rightarrow \text { Genişliği }>1 / 3 \Theta \\
{[\Theta=\text { Kovuğun }} \\
\text { bulunduğu yerdeki } \\
\text { çevre] } \\
\text {-Gövde ve/veya ana } \\
\text { dallar yaralı }\end{array}$ & $\begin{array}{l}-8 \\
-6 \\
-8\end{array}$ & & -4 \\
\hline
\end{tabular}




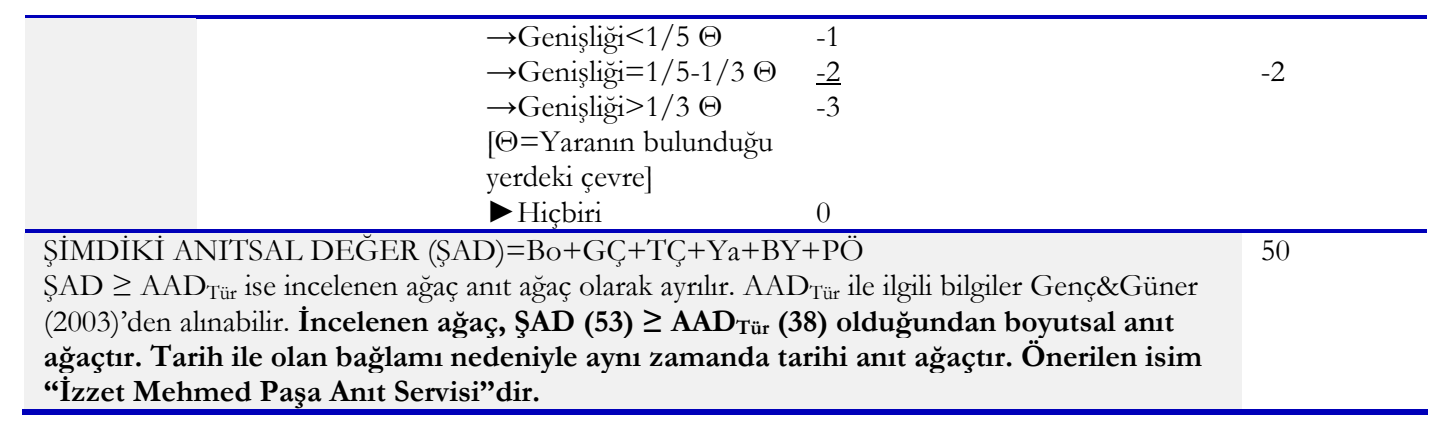

Diğer yandan anıt ağacın bulunduğu Korucuk Köyü ve komşu Beycuma’nın bilinen tarihinin yüzlerce yıl geriye gittiği ifade edilmektedir (Köktürk 2012). Fatih Sultan Mehmed devri sadrazamlarından Rum Mehmed Paşa'nın neslinden Hüseyin Bey’in oğlu olan Osmanlı Sadrazamı İzzet Mehmed Paşa (1723-1784) Bolu'ya Bağlı Çarşamba Kazası'nın Beylik Köyü'nde doğmuştur (Sarıcaoğlu 2001). Bugün idari olarak Zonguldak iline bağlı olan Çaycuma için Osmanlı Dönemi'nde Çarşamba, Hızırbeyli, Çarşamba-i Bolu gibi isimler kullanılmıştır (Sezen 2017). Çaycuma yakınlarında bulunan Beycuma'nın da içerisinde olduğu bölgede, soyadı Köktürk olan ailelerin soyağacı üzerine araştırma yapan tarih öğretmeni Mehmet Köktürk "550 Yıllık Bir Aile: Beycuma, Filyos, Mengen, Çaycuma Beyleri” başlıklı kitabında, 1690 yılı Osmanlı İmparatorluğu döneminde bu bölgenin vergi toplama ve yönetimini sağlamak için Rumbeyzade Ahmet Bey'in oğullarından Hüseyin Bey’in Beycuma Yukarı Beyliği'ne atandığını ifade etmiştir. Köktürk (2012)'e göre Çarşamba (Çaycuma) Kazası'nın Beylik Köyünde (Beycuma) 1723 yılında doğan İzzet Mehmet Paşa işte bu Hüseyin Bey’in oğludur. Araştırma konusu olan anıt servinin yaşı yıllık halka analizi çerçevesinde 386 yıl (301-400) olarak tahmin edilmiştir. Yörenin doğal türlerinden olmayan ve hesaplanan şimdiki anıtsal değeri itibariyle anıtsal özellikler gösteren bu servi ağacının, tahmin edilen yaşına göre 17. yüzyılın ikinci yarısında (muhtemelen İzzet Mehmet Paşa'nın babası Hüseyin Bey’in döneminde) dikildiği varsayılabilir. Bu bağlamda söz konusu anıt ağacın soyut özellikler itibariyle tarihsel anıt ağaç olarak nitelendirilmesi gerekir. Makalenin yazarları olarak hem boyutsal özellikleri hem de tarihsel bağlamı nedeniyle, Osmanlı Sadrazamlarından İzzet Mehmed Paşa'ya atfen, bu yaşlı servi ağacına “İzet Mehmed Paşa Anıt Servisi” adını öneriyoruz.

\section{Sonuç ve Öneriler}

"Yaş, çap ve boy itibariyle kendi türünün alışılmış ölçüleri üzerinde boyutlara sahip olan, yöre folklorunda, kültür ve tarihinde özel yeri bulunan, geçmiş ile günümüz, günümüz ile gelecek arasında iletişim sağlayabilecek uzunlukta doğal ömre sahip ağaçlar” anıt ağaç olarak tanımlanmaktadır (Asan 1992, 1999). Bu tanım çerçevesinde anıt ağaçlar, "boyutsal anıt ağaçlar", "tarihi anıt ağaçlar", "folklorik anıt ağaçlar" ve "mistik anıt ağaçlar” olmak üzere dört grup altında toplanmaktadır (Asan, 1992 ve 1999; Genç ve Güner, 2003). Tarihsel, folklorik, mistik veya boyutsal bir özellik taşımayan bir ağacın, sadece estetik ya da genetik değeri nedeniyle anıt ağaç olarak seçilmemesi gerektiği belirtilmektedir (Genç ve Güner, 2003). Keza, söğüt (Salix L) ve kızılağaç (Alnus Mill.) gibi oldukça hızlı büyüyen cinslere ait ağaçların da kuşaklar arasında bağ kurabilecek uzunlukta biyolojik ömre sahip olmamaları nedeniyle, çap ve boy itibariyle ne kadar görkemli olurlarsa olsunlar, anıt ağaç olarak değerlendirilmemesi gerektiği ifade edilmektedir (Genç ve Güner, 2003). Bu çalışmada incelenen Akdeniz servisinin hem boyutsal özellikleri hem de tarihi bir kişi ile olan zamansal bağı nedeniyle boyutsal ve tarihi anıt ağaç olarak ilgili kurum tarafından, "İzet Mehmed Paşa Anıt Servisi" adıyla tescil edilerek kayıtlara geçirilmesi önerilmiştir.

\section{Kaynaklar}

1. Akkemik, Ü. (2004). Dendrokronoloji: İlkeleri-Biyolojik Temelleri-Yöntemleri-Uygulama Alanları. İ.Ü. yayın no: 4484, O.F. yayın no: 479, İstanbul.

2. Akkemik, Ü., Demirtaş, A., Köse, N., Usta, S., Güner, H.T. (2018). Zonguldak Alaplı'daki Anıt Porsuk (Taxus baccata L.) Ağacı Gerçekten 4112 yaşında mı? Orman ve Av, 961 (2), 11-19.

3. Asan, Ü. (1992). Anıt Ağaçların Birey ve Toplum Psikolojisi Üzerine Etkileri. Yeşile Çerçeve Dergisi, sayı 18.

4. Asan, Ü. (1999). Anıtsal Karaçamlar. 1. Uluslararası Ehrami Karaçam Sempozyumu (ed. A. Tatlı, H. Ölçer, N. Bingöl ve H. Akan), s.611-622, Kütahya.

5. Genç, M., Güner, Ş.T. (2003). Göller Bölgesi'nin Anıt Ağaçları. Isparta Valiliği İl Özel İdare Müdürlüğü Yayını, 322 s., Isparta. 
6. Kırsal Çevre (2019). İç Anadolu'nun Kalıntı Ormanları. Kırsal Çevre ve Ormancılık Sorunları Araştırma Derneği, ISBN: 978-9944-0142-7-4, Arkadaş Basım Sanayi Ltd. Şti., Ankara.

7. Köktürk, M. (2012). 550 Yillı Bir Aile: Beycuma, Filyos, Mengen, Çaycuma Beyleri, soyadları Köktürk olanlar. 286 sayfa, Ankara.

8. Resmi Gazete (2020). Tabiat Varlığı Olarak Belirlenecek Anıt Ağaçların Tespitine İlişkin İlke Kararı, 24.10.2020 tarih ve 31284 sayıl1 Resmi Gazete.

9. Sarıbaş, M. (2015). Batı Karadeniz Bölgesi’nin Kayda Girmemiş Anıt Ağaçları. Ege Üniv. Ziraat Fak. Dergisi, 52(1), 13-21.

10. Sarıcaoğlu, F. (2001). İzzet Mehmed Paşa (ö.1198/1784), Osmanlı Sadrazamı. Türkiye Diyanet Vakfı İslam Ansiklopedisi, 23. cilt, sayfa 557-558.

11. Sezen, T. (2017). Osmanlı Yer Adları. T.C. Başbakanlık Devlet Arşivleri Genel Müdürlüğü, Yayın No. 26, Ankara.

12. TSE (2005). Anıt Ağaçlar - Envanter, Seçim Kuralları ve İşaretleme. Türk Standardı, TS 13137.

13. URL-1. https://www.gilroygardens.org/play/circus-trees

14. URL-2.https://www.monumentaltrees.com/en/trees/pinuslongaeva/

15. URL-3. https://www.monumentaltrees.com/en/trees/coastredwood/tallest_tree_in_the_world/

16. URL-4. https://www.monumentaltrees.com/en/trees/giantsequoia/biggest_tree_in_the_world/

17. Yaman, B. (2005). Tarihin Canlı Tanıkları: Anıt Ağaçlar. Bilim ve Gelecek Dergisi, 20, 54-57.

18. Yaman, B., Sarıbaş, M. (2007). Zonguldak-Dirgine Ormanlarında Yeni Bir Anıt Ağaç: Elemen Karaçamı. Ekoloji, 63, 62-68.

19. Yaman, B. (2009a). Wood anatomy of ivy-hosting black alder (Alnus glutinosa Gaertn.) Dendrobiology 62, 41-45.

20. Yaman, B. (2009b). Comparative wood anatomy of ivy-hosting and non-hosting oriental plane (Platanus orientalis L.). Plant Biosystems 143(2), 252-257.

21. Yaman, B. (2018). Monumental Traits of Two Old Oriental Planes in Kizilkum, Bartın. Journal of Forestry, 14(2), 71-79. 